\title{
Estimate of intrinsic safety of capacitive circuits
}

\author{
Oleksandr Hladkov, ${ }^{1, *}$, Anatolii Mnukhin ${ }^{2}$, and Rishard Stasevich ${ }^{3}$ \\ ${ }^{1}$ Daughter enterprise «Production and engineering firm «SHATL», 50005, Kryvyi Rih, Tbiliska Str., \\ 11, Ukraine \\ ${ }^{2}$ State engineering academy Zaporizhzhia, 69006, Zaporizhzhia, Sobornyi Ave., 226, Ukraine \\ ${ }^{3}$ Institute of Geotechnical Mechanics named by N. Poljakov of National Academy of Sciences of \\ Ukraine, 49005, Dnipro, Simferopolska Str., 2a, Ukraine
}

\begin{abstract}
A universal method has been developed and tested for computer estimate of intrinsic safety of inductive capacitive circuits, which takes into account the most hazardous discharge type by contact closure and the regression dependences are obtained of minimal igniting energy on discharge time in a capacitive circuit and the comparison is made of results with available experimental dependences. A regression equation is received which connects minimal igniting energy and discharge time as well as voltage of a capacitive circuit. The comparison of the results with available experimental dependencies is made. The intrinsic safety parameters are defined which leads to decrease of risk for explosion and freely burning fire in a coal mine.
\end{abstract}

\section{Introduction}

Explosion safety of industrial processes in coal industry of Ukraine is an integrant part of labour protection and safety system. One of the main principles of decrease of explosion risk is prevention of active ignition sources by means of use of prevention measurements in mine equipment - explosion protection types.

The most effective of these measurements is explosion protection type "intrinsic safe electric circuit "i". It creates such conditions that an electric discharge in a circuit and heated equipment components cannot ignite explosion medium by ordinary operation and taking into account the damage of equipment components considered $[1,2]$ even in presence of explosive atmosphere carrying voltage. This property unique for this explosion protection type as well as a variety of other advantages (lesser weight and dimensions of the product, a more simple manufacturing technique and corresponding a lesser price) causes its widespread use in mine connecting, monitoring an aerogas control devices etc.

Implementation of a capability of explosion protection type "intrinsic safe electric circuit" is inherent in solving of the problem of objectivity increase of evaluation method for valid parameter, development labor input decrease by means of development of new beadless evaluation methods of intrinsic safety of electric circuits. At the present time, for the purpose of beadless evaluation of intrinsic safety of capacitive circuits the dependences of minimal igniting voltage on capacity are used taking into account the limiting resistance

\footnotetext{
*Corresponding author: gladkov55@ukr.net
} 
obtained for essential gas mixtures (GOST 22782.5, IEC 60079-11, DSTU EN60079-11). Circuits with severe conformity to dependences provided occur rare in actual practice; their use is limited to a short range of capacity values of capacitor and resistance of limiting resistor for which these dependences are available. Therewith, inductive elements often occur in discharge resistor circuits and the complex evaluation of intrinsic safety for a common case of branched circuit is impossible. Therefore the development of estimate of intrinsic safety of such circuits is a relevant objective.

The purpose of this research work is the development and the testing of universal method for computer estimate of intrinsic safety of inductive capacitive circuits, which takes into account the most hazardous discharge type by contact closure and the obtainment of regression dependences of minimal igniting energy on discharge time in a capacitive circuit and the comparison of results with available experimental dependences.

\section{Methods}

In most cases occurring in actual practice the evaluated capacitive circuits of intrinsic safe equipment can come down to circuits (Fig. 1) consisting of a series-parallel connection of direct-current power supply $E$, condenser $C$, direct-current resistances $R$, inductor $L$ and sparking switching appliance $S M$ (Fig. 1 a). A circuit can also include a condenser $C$ or a cable, shunting inductor $L$ with the resistance $R$ or shunting a discharge gap (Fig. 1, b, c).

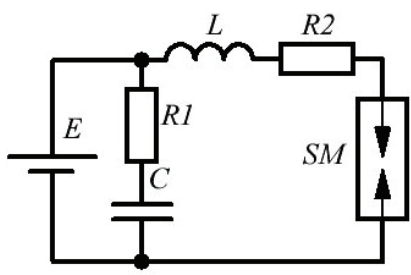

a)

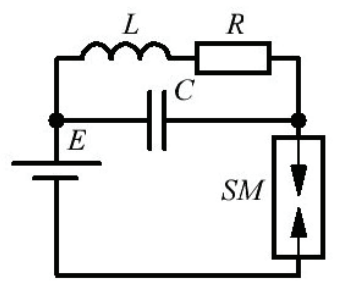

b)

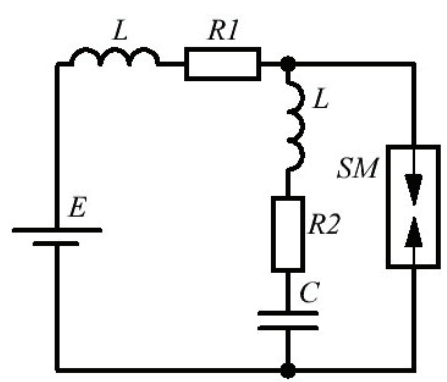

c)

Fig. 1. Equivalent schemes of capacitive circuits.

For inductance-capacitance circuits in research work [3] mathematical expressions are derived, which determinate discharge duration $T_{\mathrm{p}}$, peak current $i_{\max }$ and short circuit discharge $W_{\mathrm{p}}$. However, their use demands knowledge of transition process character (nonperiodic, oscillation discharge, critical behavior). Besides, they are not suitable for evaluation of intrinsic safety of capacitive circuits in real schemes including complex combination of components.

The special aspects of suggested method for evaluation of intrinsic safety of capacitive circuits come down to development of a universal computer model of contact closure discharge and obtainment of regression dependences of minimal igniting energy on discharge time in a capacitive circuit.

The development of a universal computer model of contact closure discharge was carried out with the help of empirical and theoretical studies, which are outlined as follows.

In intrinsic safety a single short circuit and intermittent sparking are considered. These two types of spark formation are used by testing of circuits with live capacitors in inductance-capacitance circuits being the most aggressive in respect of ignition of explosive gas mixtures [4]. It has been validated experimentally, that for these types of discharge the same model of current decrease can be taken [5]. The process of spark forming by contact closure includes several stages. By approach of electrodes of switching appliance $S M$ its 
voltage corresponds to voltage of power supply source of the circuit $E$. By touching of contacts discharge current occurs, which causes intensive evaporation of contact metal and forming of streamers - narrow conductive (filled with plasma) channels coming from one of the electrodes for a time period of $0.1 \mu \mathrm{s}$ [6]. Thus the time constant for this process $\tau$ amounts to 33-34 $\mathrm{ns}^{-1}$. This process is accompanied by voltage decrease on discharge gap due to exponential law from power supply source voltage of circuit $E$ to steady-state value $U_{0}$. It remains constant during the whole discharge $U_{p}=$ const $=U_{0}$ [3]. According the data of experimental studies [7] we take the value $U_{0}=9 \mathrm{~V}$. Disappearance of the arc is caused by decrease of discharge current to the value of $i_{p}=i_{0}<250 \mathrm{~mA}$ for single short circuits and 3$20 \mathrm{~mA}$ for intermittent sparking. After that a metal contact closure occurs - the voltage tends to zero. Consequently, equation describing the transition process of voltage changing on discharge $U_{p}(t)$ including the above mentioned stages of short circuit discharge occurrence is as follows

$$
U_{p}(t)=\left(E-U_{0}\right) e^{-\tau t}+U_{0} .
$$

The spark forming mechanism can be conveniently conceived of as mathematical (computer) model, representing the discharge characteristics of capacitive circuit (1) trough the discharge resistance (Fig. 2)

$$
R_{p}(t)=\frac{U_{p}(t)}{I_{p}(t)}=\frac{\left(E-U_{0}\right) e^{-\tau t}+U_{0}}{I_{p}(t)}=\frac{(E-9) e^{-34 \cdot 10^{9} t}+9}{I_{p}(t)} .
$$

The switch $S W 2$ ensures the startup of discharge transition process. In initial state it is disconnected, which ensures the charge of condenser $C 1$ to voltage value of power supply source $E$. The transition process is started at the moment of switch connection (in $10 \mu \mathrm{s}$ ). Resistors $R 1, R 2$ exclude the influence of power supply source on discharge parameters by means of current restriction to $2 \mathrm{~mA}$. The switch $S W 1$ in initial state is connected, which ensures the presence of open-circuit voltage of power supply source $E$ on spark forming mechanism before the startup of transition process. Resistor $R O=0.1 \mathrm{Ohm}$ determines the resistance of cables, cell terminals etc. The model $S M$ shows the changes in time of resistance of discharge gap (2), which in its turn depends on parameters of discharge circuit. The capacitive circuit under consideration consists from condenser $C 1$, resistor $R 3$ and inductor $L 1$.

The computer model (Fig. 2) is basis for obtainment of base data by using the method of process modeling of arc commutation in capacitive electric circuits for their evaluation: discharge energy $W_{\mathrm{p}}\left(T_{\mathrm{p}}\right)$, discharge duration $T_{\mathrm{p}}$. It is recommended to determine the calculation of discharge time as a relative peak time of discharge current curve $I(S M)$ between the beginning of its growth and the current value of discharge break $I(t)=i_{0}=3 \mathrm{~mA}$ (Fig. 3). The discharge energy is determined graphically by value of running time corresponding to discharge duration.

\section{Results and discussion}

The developed computer model of a short circuit discharge (Fig. 2) makes it possible to determine the estimated dependence of energy and time of existing of a short circuit discharge in inductance-capacitance circuit for evaluation of intrinsic safety of complex circuits which parameters are missing in regulatory documents.

Studies of igniting ability of capacitive circuits with limiting resistor in discharge circuit according to DSTU EN60079-11 give background for determination of evaluated 
dependence of minimal igniting (allowable) energy on discharge time both in capacitive and inductance-capacitance circuits with limiting resistor for group I. As a result, the regression equations are obtained for explosive mixture of group I connecting minimal igniting energy (3)-(5), discharge time and voltage of capacitive circuit. Both model and dependences obtained allow to make a comparative evaluation of intrinsic safety due to released energy in capacitive circuit with a certainty of not less than $15 \%$ compared to curves [8].

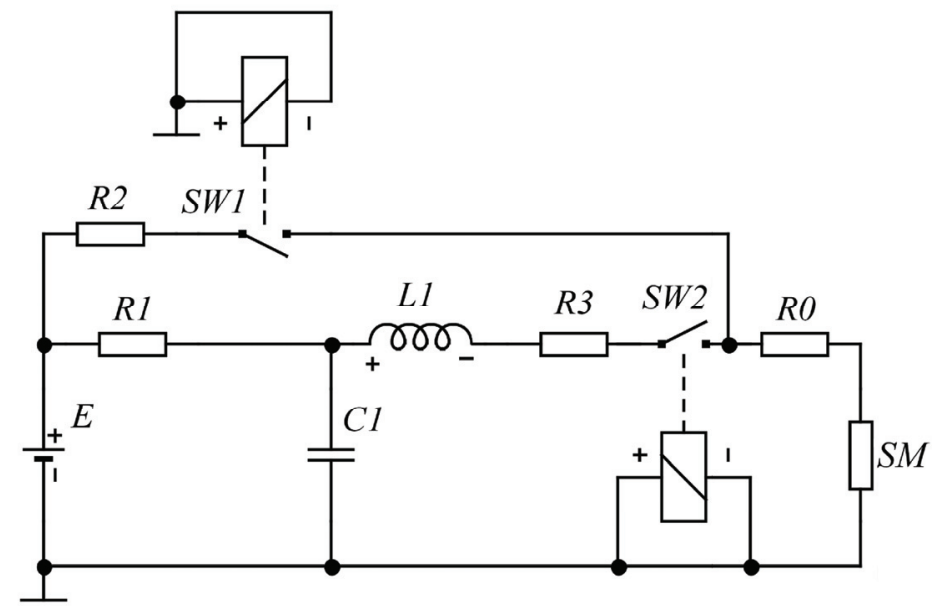

Fig. 2. Scheme of computer model for calculation of discharge parameters of an intrinsic safe capacitive circuit.

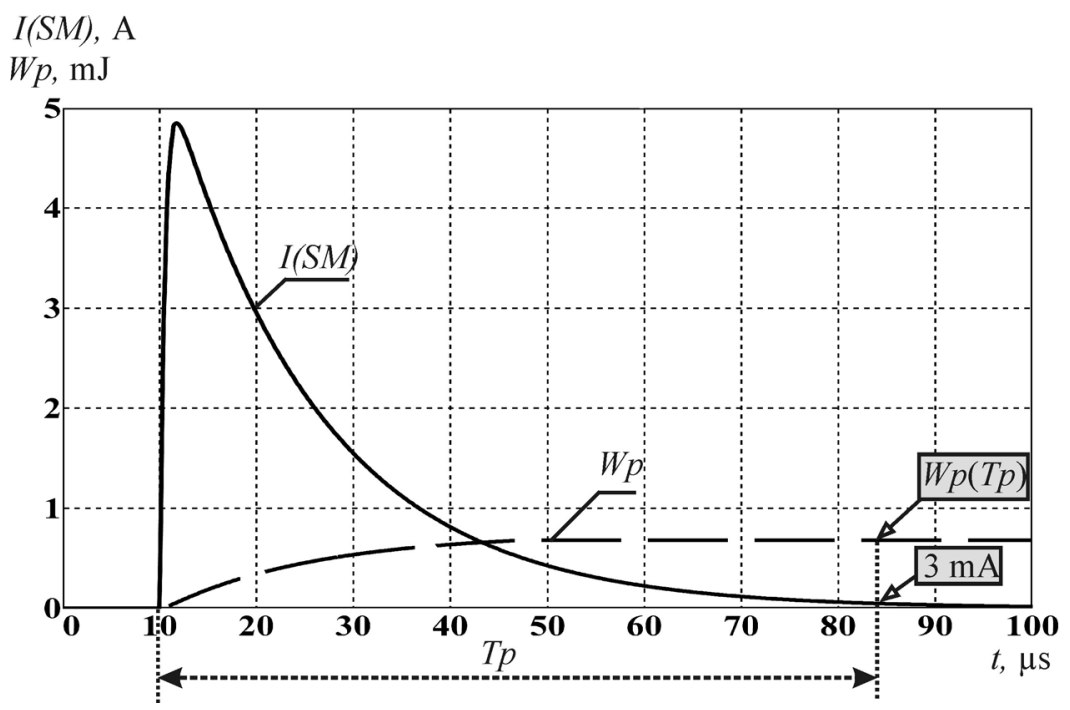

Fig. 3. Dependences of main short circuit discharge on time.

The evidence for proper use of computer model taken is comparison of calculated and experimental values for discharge duration and discharge energy (Table 1) by arc brake current of $3 \mathrm{~mA}$ and resistor of $R 3=3.8 \mathrm{Ohm}$. The experimental data are obtained by means of standardized spark forming mechanism [8] by means of fixation of transition process of discharge current and voltage with digital oscilloscopeTDS2022. 
Table 1. Comparison of experimental and calculated values for discharge time and maximum current surge in capacitive circuits.

\begin{tabular}{|c|c|c|c|c|c|c|c|c|}
\hline \multirow{2}{*}{$>$} & \multirow{2}{*}{$\frac{\sqrt[L]{J}}{\widetilde{U}}$} & \multirow{2}{*}{$\begin{array}{l}\underset{\Xi}{\Xi} \\
\Xi\end{array}$} & \multicolumn{3}{|c|}{ Experimental curves } & \multicolumn{3}{|c|}{ Model } \\
\hline & & & $W_{p}, \mu \mathrm{J}$ & $T_{p}, \mu \mathrm{s}$ & $I_{\max }, \mathrm{A}$ & $W_{p}, \mu \mathrm{J}$ & $T_{p}, \mu \mathrm{s}$ & $I_{\max }, \mathrm{A}$ \\
\hline 30 & 4 & 0 & 715 & 39.0 & 5.1 & 680 & 38.0 & 5.3 \\
\hline 50 & 4 & 0 & 1430 & 49.0 & 10.0 & 1397 & 48.3 & 10.4 \\
\hline 70 & 4 & 0 & 2150 & 55.0 & 15.3 & 2117 & 54.7 & 15.4 \\
\hline 30 & 4 & 2 & 680 & 39.0 & 5.0 & 680 & 37.6 & 4.9 \\
\hline 50 & 4 & 2 & 1428 & 49.3 & 9.2 & 1390 & 47.8 & 9.4 \\
\hline 70 & 4 & 2 & 2150 & 55.0 & 14.0 & 2100 & 54.0 & 14.0 \\
\hline
\end{tabular}

The reproducibility of modeling in response to experimental data does not exceed $5 \%$ (Table 1), which characterizes this model as a relative precise one.

The obtainment of regression dependences of allowable igniting energy on discharge time in capacitive circuit was made by means of methods of empiric and experimental studies which are outlined as follows.

In accordance with dependence of minimal igniting voltage on circuit capacity for group I [8] the values of electric circuit parameters are determined: resistance of current limiting resistor $R$, Ohm as well as capacities $C, \mu \mathrm{F}$ by circuit voltage of $E=20 \mathrm{~V}, 30 \mathrm{~V}$, $50 \mathrm{~V}, 70 \mathrm{~V}, 100 \mathrm{~V}, 200 \mathrm{~V}, 300 \mathrm{~V}$. With the help of computer model (Fig. 2) by $L 1=0$, arc brake current of $3 \mathrm{~mA}$ the values are calculated for discharge energy $W_{B}$ and its duration $T_{\mathrm{p}}$ for these capacitive circuits (Table 2, Fig. 4).

Table 2. Results of modeling of igniting parameters.

\begin{tabular}{|c|c|c|c|c|c|c|c|c|c|}
\hline \multicolumn{3}{|c|}{ Circuit parameters } & \multicolumn{2}{c|}{$\begin{array}{c}\text { Discharge } \\
\text { parameters }\end{array}$} & \multicolumn{2}{c|}{ Circuit parameters } & \multicolumn{2}{c|}{$\begin{array}{c}\text { Discharge } \\
\text { parameters }\end{array}$} \\
\hline$E, \mathrm{~V}$ & $\begin{array}{c}R 3, \\
\mathrm{Ohm}\end{array}$ & $\begin{array}{c}C 1, \\
\mu \mathrm{F}\end{array}$ & $T_{p}, \mathrm{~ms}$ & $W_{B}, \mathrm{~mJ}$ & $E, \mathrm{~V}$ & $\begin{array}{c}R 3, \\
\mathrm{Ohm}\end{array}$ & $\begin{array}{c}C 1, \\
\mu \mathrm{F}\end{array}$ & $T_{p}, \mathrm{~ms}$ & $W_{B}, \mathrm{~mJ}$ \\
\hline 20 & 0 & 24.0 & 0.0466 & 2.372 & 100 & 0 & 0.68 & 0.0005 & 0.736 \\
\hline 20 & 5.6 & 200.0 & 7.5100 & 19.700 & 100 & 5.6 & 2.50 & 0.1240 & 2.044 \\
\hline 30 & 0 & 7.2 & 0.0147 & 1.361 & 100 & 15.0 & 4.70 & 0.5460 & 3.816 \\
\hline 30 & 5.6 & 28.0 & 1.1570 & 5.255 & 100 & 40.0 & 9.00 & 2.4070 & 7.292 \\
\hline 30 & 15.0 & 90.0 & 8.4270 & 16.869 & 200 & 0 & 0.22 & 0.0003 & 0.997 \\
\hline 50 & 0 & 2.4 & 0.0050 & 0.922 & 200 & 5.6 & 0.80 & 0.0430 & 1.442 \\
\hline 50 & 5.6 & 9.0 & 0.4070 & 3.295 & 200 & 15.0 & 1.50 & 0.1900 & 2.583 \\
\hline 50 & 15.0 & 18.0 & 1.8690 & 6.579 & 200 & 40.0 & 2.70 & 0.8030 & 4.602 \\
\hline 50 & 40.0 & 60.0 & 14.128 & 21.892 & 300 & 0 & 0.12 & 0.0001 & 1.195 \\
\hline 70 & 0 & 1.3 & 0.0025 & 0.801 & 300 & 5.6 & 0.43 & 0.0237 & 1.288 \\
\hline 70 & 5.6 & 4.9 & 0.2320 & 2.672 & 300 & 15.0 & 0.75 & 0.1000 & 2.022 \\
\hline 70 & 15.0 & 8.6 & 0.9450 & 4.677 & 300 & 40.0 & 1.50 & 0.4720 & 3.915 \\
\hline 70 & 40.0 & 22.0 & 5.5320 & 11.945 & & & & & \\
\hline
\end{tabular}

For data package obtained for $W_{\mathrm{B}}$ and $T_{\mathrm{p}}$ (Table 2) analytical dependences $W_{B}\left(T_{p}\right)$ are found by means of approximation with the help of most suitable regression equations. For voltages $E: 20-50 \mathrm{~V}$

$$
W_{B}\left(T_{p}\right)=a_{20 \_50}(E) \cdot \ln \left(T_{p}\right)+b_{20 \_50}(E) \cdot \sqrt{T_{p}}+c_{20 \_50}(E) \cdot T_{p} ;
$$

for voltages E: $50-100 \mathrm{~V}$ 


$$
W_{B}\left(T_{p}\right)=a_{50 \_100}(E) \cdot \ln \left(T_{p}\right)+b_{50 \_100}(E) \cdot \sqrt{T_{p}}+c_{50 \_100}(E) \cdot T_{p}+d_{50 \_100}(E)
$$

for voltages $E: 100-300 \mathrm{~V}$

$$
W_{B}\left(T_{p}\right)=a_{100 \_300}(E) \cdot \ln \left(T_{p}\right)+b_{100 \_300}(E) \cdot \sqrt{T_{p}}+c_{100 \_300}(E) .
$$

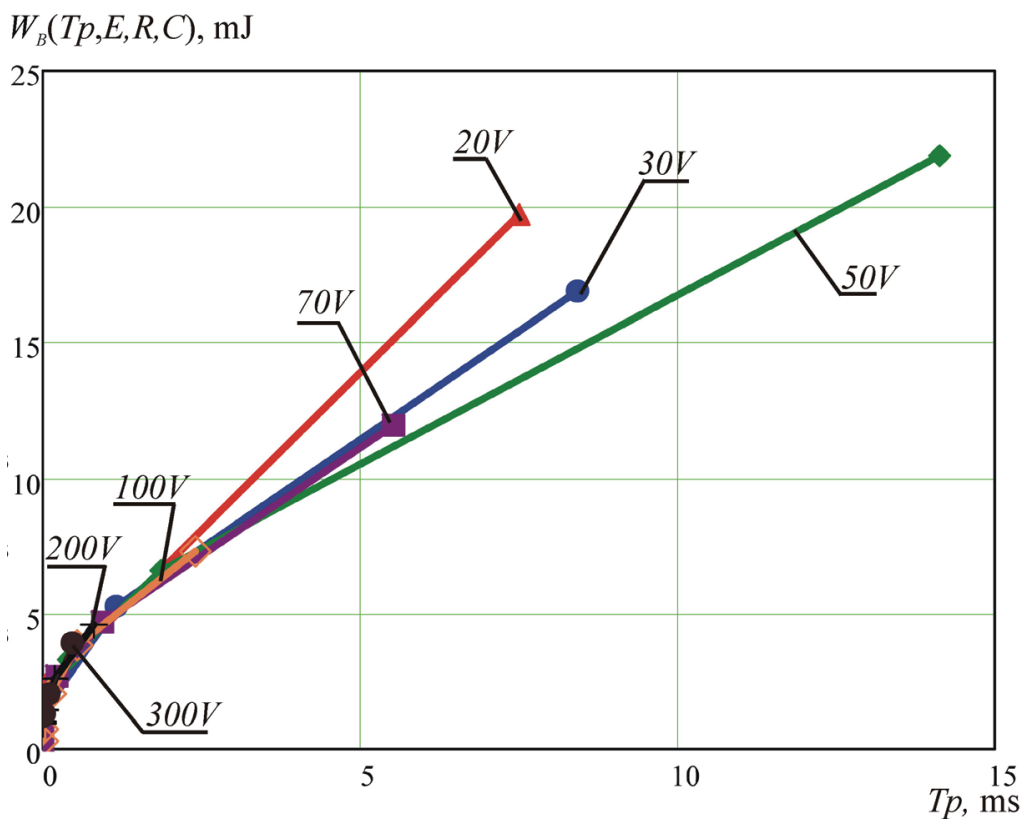

Fig. 4. Results of modeling of igniting parameters.

For each voltage $E$ approximation coefficients are found and correlation coefficient is evaluated. Approximation accuracy in all cases is 0.99 . For data package groups obtained for coefficients determined by voltage range of $20-50 \mathrm{~V}, 50-100 \mathrm{~V}$ and $100-300 \mathrm{~V}$, their analytical dependences are found by means of approximation with the help of most suitable regression equations as well as approximation coefficients (6-15):

$$
\begin{gathered}
a_{20 \_50}(E)=5.46482 \cdot 10^{-4} \cdot \ln (E)-1.5901 \cdot 10^{-4} \cdot \sqrt{E}-1.0699 \cdot 10^{-3} ; \\
b_{20 \_50}(E)=-0.27524 \cdot \ln (E)+0.09511 \cdot \sqrt{E}+0.52917 ; \\
c_{20 \_50}(E)=-1.96566 \cdot \ln (E)+0.48255 \cdot \sqrt{E}+4.75756 ; \\
a_{50 \_100}(E)=3.35309 \cdot 10^{-3} \cdot \ln (E)-8.47823 \cdot 10^{-4} \cdot \sqrt{E}-7.03139 \cdot 10^{-3} ; \\
b_{50 \_100}(E)=-1.40448 \cdot \ln (E)+0.35628 \cdot \sqrt{E}+3.0711 ; \\
c_{50 \_100}(E)=17.92744 \cdot \ln (E)-4.58814 \cdot \sqrt{E}-37.0445 ; \\
d_{50 \_100}(E)=0.03506 \cdot \ln (E)-8.79152 \cdot 10^{-3} \cdot \sqrt{E}-0.07319 ;
\end{gathered}
$$




$$
\begin{aligned}
& a_{100_{3} 300}(E)=-1.91183 \cdot 10^{-6} \cdot \ln (E)-6.48252 \cdot 10^{-7} \cdot E+3.93709 \cdot 10^{-5} ; \\
& b_{100_{3} 300}(E)=-0.04866 \cdot \ln (E)+4.87319 \cdot 10^{-4} \cdot E+0.31438 ; \\
& c_{100_{3} 300}(E)=-4.77263 \cdot 10^{-4} \cdot \ln (E)-1.02811 \cdot 10^{-5} \cdot E-7.78864 \cdot 10^{-4} .
\end{aligned}
$$

Approximation accuracy for all equations (6-15) is 0.99 .

Estimation of intrinsic safety of capacitive circuits comes down to calculation of values of released discharge energy $W_{p}$ and its duration $T_{p}$ by means of modeling of the circuit being estimated with the help of computer model (Fig. 2) taking into account reserve coefficient $1.5 \cdot E$, determination of minimum igniting energy $W_{B}\left(T_{p}\right)$ due to (3-5) taking into account (6-15) depending on circuit voltage $E$. The criterion for intrinsic safety is fulfillment of the following condition:

$$
W_{B}\left(T_{p}\right)-W_{p}\left(T_{p}\right) \geq 0
$$

Let us consider the developed methods for evaluation of intrinsic safety by the example of the scheme (Fig. 2) with following parameters $E=40 \mathrm{~V}, R 3=5.6 \mathrm{Ohm}$ and $C 1=12 \mu \mathrm{F}$, $13.5 \mu \mathrm{F}$ and $15 \mu \mathrm{F}$. The dependence of allowable igniting energy on discharge time $W_{B}\left(T_{p}\right)$ from the formula (3) taking into account (6)-(8) is set out in Figure 5.

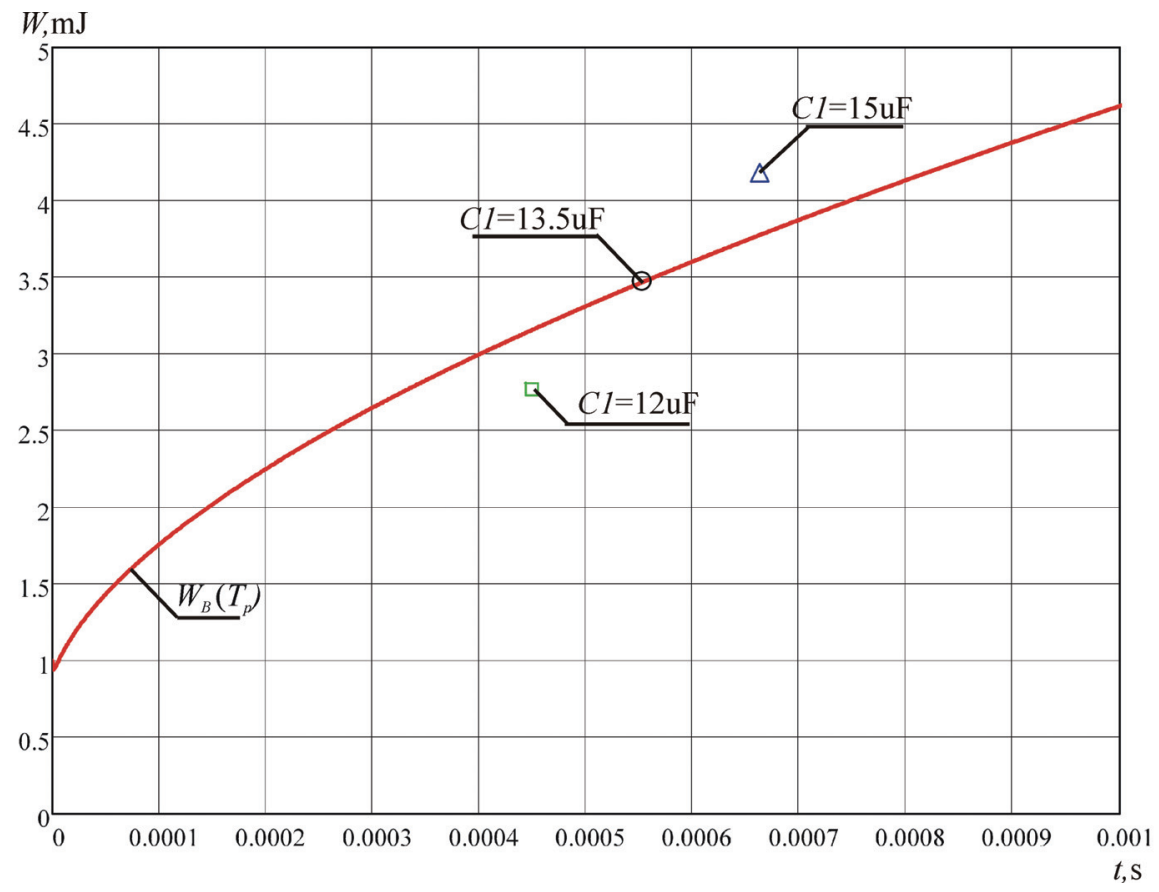

Fig. 5. Dependence of allowable igniting energy (full line) and energy released in discharge on time.

The diagram in Figure 5 shows reference points for capacities $C l=12 \mu \mathrm{F}, C l=13.5 \mu \mathrm{F}$, $C 1=15 \mu \mathrm{F}$, respectively. For the three capacity values, the condition of compliance with intrinsic safety (16) is fulfilled for 12 and $13.5 \mu \mathrm{F}$ only.

In accordance with GOST curves for indicated parameters the allowable capacity does not exceed $15 \mu \mathrm{F}$. 
As follows from the analysis, the discordance between data obtained and GOST data does not exceed $15 \%$.

\section{Conclusions}

The use of method for assessment of electric circuits of intrinsic safe equipment being developed for gaseous mines reduces significantly the time of its implementation with more exact following the parameters of intrinsic safety and leads therefore to risk reduction of an explosion and freely burning fire occurrence.

\section{References}

1. Gladkov, O.Yu., Mnukhin, A.G., Shmanyov, S.V. (2018). Optymizatsiya shakhtnoho osvitlennya $\mathrm{z}$ urakhuvannyam hranychnykh parametriv iskrobezpeky, Suchasni resursoenerhozberihayuchi tekhnolohiyi hirnychoho vyrobnytstva, 2 (22), 94-106

2. Gladkov, A.Yu., Boltunov, O.G., Tarasenko, S.L. (2015). Metod rascheta parametrov sistem osveshcheniya dlya otsenki ikh iskrobezopasnosti, Sposoby i sredstva sozdaniya bezopasnykh i zdorovykh usloviy truda v ugol'nykh shakhtakh. Trudy MAKNII, 1 (35), 46-55

3. Erygin, A.T., Trembitsky, A.L., Yakovlev, V.P. (1984). Metody otsenki iskrobezopasnosti elektricheskikh tsepey. Moskva: Nauka

4. Petrenko, B.A. (1963). Elektricheskiy razryad v iskrobezopasnykh tsepyakh. Mekhanizatsiya i avtomatizatsiya v gornoy promyshlennosti, 3, 300 - 317

5. Kravchenko, V.S., Serov, V.I., Erygin, A.T., Pogorelsky, A.E. (1976). Iskrobezopasnost elektricheskikh tsepey. Moskva: Nauka

6. Kogan, E.G. (1988). Sposoby i sredstva obespecheniya iskrobezopasnosti rudnichnogo elektrooborudovaniya. Moskva: Nedra

7. Didenko, V.P. (2007). Sovremennyye podkhody k otsenke i obespecheniyu iskrobezopasnosti elektricheskikh tsepey. Ugol Ukrainy, 9, 39-42

8. DSTU EN 60079-11:2016. (2016). Vybukhonebezpechni hazovi seredovyshcha. Chastyna 11. Zakhyst elektrychnoho obladnannya za dopomohoyu iskrobezpechnoho elektrychnoho kola (i). Kyiv: DP "UkrNDNTS" 